日植病報 $70: 161$ (2004)

Jpn. J. Phytopathol. 70 : 161 (2004)

\title{
学術奨励賞受賞者研究要旨
}

\section{ウリ類炭そ病菌の感染機構に関する分子遺伝学的研究 †}

\author{
高 野 義 孝*
}

TAKANO, Y.*: Molecular genetic studies on infection mechanism in Colletotrichum lagenarium

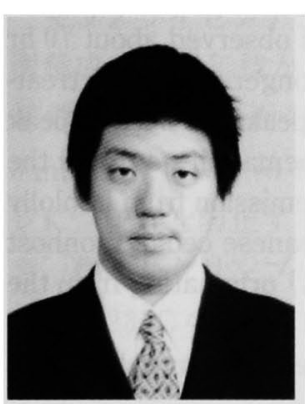

多くの植物病原采状菌の胞子 は，宿主植物上において発芽した 後, 発芽菅の先端に付着器と呼ば れる侵入器官を形成し, 植物体人 の侵入を行う. 胞子が行うこれら の形態分化は，自身が位置する外 界の認識を起点として進行してい くと推定される.生物は外界加ら の刺激に対する認識とそれに対応

した反応を慗ぐ制御系として，様々な細胞内シグナル伝達 経路を有しているが，病原菌の感染機構に対してのシグナ ル伝達経路の役割については，十分な知見は得られていな い. 本研究においては, ウリ科植物に病害を引き起こす ウリ類炭そ病菌（Colletotrichum lagenarium）における Mitogen-Activated Protein (MAP) キナーゼ経路および cAMP 依存性タンパクキナーゼ（PKA）経路に焦点を当 て，これらの細胞内シグナル厷達経路が本菌の感染機構へ 果たす役割について研究を行った.

\section{MAP キナーゼ経路についての解析}

ウリ類炭そ病菌より MAP キナーゼをコードする遺伝子 を単離し，それぞれを OSC1，MAF1 およびCMK1 と名 付けた。 $M A F 1$ 遗伝子破壊株を作出した結果, 本破壊株 は栄盖培地上での生育度においては野生株と同等であるの に対し，宿主植物であるキュウリに対しての病原性は䫓著 に低下していた．MAF1 破壊株の分生胞子は正常に発芽 したが，付着器への分化を全く示さなかった.これらの結 果より, MAF1 が植物病原菌の病原性発現に関与し, 付 着器分化の制御に必須であることを明らかにした。

$C M K 1$ 遺伝子破壊株を作出し解析した結果より， $C M K 1$ は本菌の病原性発現に必須であることを明らかに
した．破壊株は，発芽過程での欠損を示した，一方，酵母 エキス溶液で胞子培盖を行った結果, その発芽欠損は相補 された。しかし，発芽した破壊株の胞子は付着器様の膨張 した細胞構造を形成しつつも野生株とは異なり正常な付着 器を形成せず, CMKI が付着器形成に関与していること が判明した。これらの結果より，CMKIが感染時の形態 分化過程を多面的に制御していることが明らかとなった。

\section{PKA 経路についての解析}

cAMP シグナル伝達経路の役割を調査するため, PKA の制御サブユニットをコードする $R P K 1$ 遺伝子を, ウリ 類炭そ病菌より単離してその機能解析を行った。 RPKI 破 壊株を作出した結果, 本破壊株は恒常的な PKA 活性を示 し, 栄養培地上での生育度, 胞子形成, 及び宿主植物に対 する病原性の顕著な低下を示した。この結果より，恒常的 な PKA 活性がこれらの過程に阻害的影響を与えることを 示した. また， $R P K 1$ 破壊株加ら生育の回復を示すサプレ ッサー変異株 SGClを分離し，その表現型を調べた結 果, SGC1株は RPK1 破壊株同様に病原性欠損を示し た. SGC1 株はPKAの触媒サブュニット遺伝子 CPK1に アミノ酸置換を伴う突然変異を有しており, PKA 活性を 失っていた。この結果より, PKA 活性は本菌の病原性に 必要であることが強く示唆された。 RPK1破壊株および SGC1は共に宿主植物上において付着器を形成したが，侵 入菌系形成は観察されず, 両株とも付着器を介した侵入過 程での久損を示した．これらの結果より，角皮侵入のため の付着器の機能発現には, 適切な PKA 活性の制御が必要 であることが強く示唆された。

本研究を行うにあたり，多くの方々に，終始ご指導とご 協力を賜りました。この場を借りて，深く感謝の意を表し ます。

\footnotetext{
†平成16年 3 月 28 日 平成 16 年度大会で受賞した学術奨励賞研究の要旨

* 京都大学大学院農学研究科 Graduate School of Agriculture, Kyoto University, Sakyo-Ku, Kyoto 606-8502, Japan
} 